\title{
SOVEREIGN DEBT AND JOINT LIABILITY: AN ECONOMIC THEORY MODEL FOR AMENDING THE TREATY OF LISBON*
}

\author{
Kaushik Basu and Joseph E. Stiglitz
}

\begin{abstract}
As the euro area crisis drags on, it is evident that a part of the problem lies in the architecture of debt within the euro area. This study argues that at least part of the debt problem could be addressed through limited cooperative action entailing appropriately structured contracts generating crosscountry liability for sovereign debt incurred by individual nations within the European Union. Such agreements are currently proscribed by the Treaty of Lisbon. We construct a game-theoretic model demonstrating that there exist self-fulfilling equilibria, which are Pareto superior to the existing outcome and which would come into existence if cross-country debt liabilities were permitted.
\end{abstract}

As the euro area crisis drags on, it has become increasingly clear that a part of the problem lies in the architecture of debt in the construction of the euro area and, more generally, the European Union. This is the reason why the assurance from the European Central Bank (ECB) in July 2012 that it was prepared to do "whatever it takes' to preserve the euro boosted morale and markets. It led to a sense that the sovereign debt of an individual nation, however small, within the euro area, had an assurance that went beyond the boundaries of the nation.

Yet, while that did play a vital role in calming markets, bringing down sovereign yields and preventing the euro area from spinning into a full-blown financial crisis, it has failed to boost growth and mitigate unemployment, and euro area countries continue to drift in and out of recession. Indeed, there is an increasing realisation now that the ECB may want to do 'whatever it takes', but will do 'whatever is possible', and there are severe limits to the latter. This was explicitly stated in Germany's constitutional court in Karlsruhe in June 2013, when the Bundesbank questioned the ECB's open-ended offer to buy sovereign bonds of nations at risk of default. ${ }^{1}$ Some of this scepticism about the extent to which the ECB or any nation can reach out to rescue another nation in the euro area caught up in the sovereign debt crisis is valid because of the restrictions placed on such action in the Treaty of Lisbon, and the earlier Treaty of Maastricht. We are referring, in particular, to articles in the Treaty

\footnotetext{
* Corresponding author: Kaushik Basu, The World Bank, 1818 H Street, NW, Washington, DC 20433, USA; Department of Economics, Uris Hall, Cornell University, Ithaca, NY 14853, USA. Email: kbasu@world bank.org, kb40@cornell.edu.

For helpful comments we are grateful to Karna Basu, Tito Cordella, Jose Luis Diaz Sanchez, Vivian Hon, Celestin Monga, Tamara McGavock, Luis Serven, Komal Sri-Kumar, Aristomene Varoudakis and Boyang Zhang. We would also like to record our thanks to Bintao Wang for research assistance and to two anonymous referees and an editor of the journal for many helpful suggestions.

1 The ECB subsequently launched a 60 billion euro-a-month bond buying programme. But this comes with several fine-print restrictions. Greece, for instance, is excluded from this programme, at least to start with. Further, most of the losses from default or restructuring of debt will be borne by respective national central banks.
} 
which prohibit one nation from taking on the debt liability of another nation and also prevent the ECB from directly purchasing bonds issued by euro area sovereigns.

These features of the Lisbon Treaty are weaknesses that may not have been fully anticipated when the Treaty was being drafted. But now, with the hindsight of the fullblown euro area crisis, the fault lines have become evident and the treaty deserves amendment. This article is an attempt to provide an analytical foundation for such an amendment.

At a more general level, this article is concerned with international policy coordination, in particular, one involving banking, investment and sovereign debt. ${ }^{2}$ These cannot always be left to natural market forces and may require deliberate, global policy intervention. With globalisation the world has gradually drifted towards a single economy. This has meant that in some ways we have moved back to our predicament three hundred years ago when we had many money creating authorities operating within each economy (Stiglitz, 2015). Since the world is not about to move to a single monetary authority (the travails of Europe has set such an agenda even further back) the need is for greater coordination across central banks and governments.

Our article focuses on a narrow segment of this large agenda. We show how, by adopting a limited contractual approach, through the use of carefully crafted, bilateral agreements, welfare among several interacting nations can be enhanced.

An important question which we do not address here is: why did Europe impose the constraints on risk sharing in the first place? The fact that the restriction on the ECB's direct purchase of sovereigns could fairly easily be circumvented, simply by buying the bonds in the secondary market, suggests that the restrictions may not have been thought through thoroughly. A full investigation into this however lies beyond the scope of the present study.

\section{The Basic Model}

The bulk of international lending in the world takes place on a bilateral basis. A bank, for instance, lends to a country $j$ that uses the borrowed money and is expected to pay back the loan later (with interest). The lender, of course, does not have to be a bank; it can be an investment company or a country. There are occasions when $j$, for instance, a small country, will be unable to pay back when the time comes for repayment. ${ }^{3}$ This possibility of 'bankruptcy' and, more importantly, the awareness on the part of the agents that this may happen, affect the functioning of the credit market in fundamental ways. ${ }^{4}$ This age-old problem has acquired a new dimension with the current euro area sovereign debt crisis, as witnessed in the case of the three-year rescue package that was agreed on 2 May 2010 to prevent Greece from getting into a 'rollover crisis', caused by Greek sovereign bond yields shooting up to a spread of nearly 900

\footnotetext{
${ }^{2}$ This is an area where market failures and inefficiencies are common in the best of times (Basu, 1991; Stiglitz, 2002).

${ }^{3}$ Countries do not, of course, literally go bankrupt. For a country in crisis imposing taxes to collect the revenues necessary to fund the repayment could impose a level of hardship that is politically unacceptable. Indeed, it might not be physically possible to collect the revenues.

${ }^{4}$ It can, for instance, give rise to credit rationing and other 'distortions' in the market. In the absence of this risk, presumably no sovereign would have to pay an interest rate in excess of the US T-bill rate.
} 
basis points over German bunds, effectively cutting off Greece's access to the bond market (Zettelmeyer et al., 2013). The arrival of a new government in Greece demanding fundamental shifts in the strategies pursued by the Troika (International Monetary Fund, European Commission and the European Central Bank) makes the model presented here especially relevant to the euro area.

The problem posed by sovereign default within the euro area was again in evidence, when two years after the start of the Greek crisis, it became transparent that Cyprus was unable to repay its large international loans. ${ }^{5}$ It had accumulated a debt liability that was too large for its relatively small economy to service. At the same time, from the point of view of the euro area as a whole and even from the perspective of a single, large economy of the euro area, such as Germany or France, the debt burden of Cyprus was trivially small.

The root of the problem lies in the construction of the euro area. Entering into a monetary union alters the character of sovereign debt radically, since no individual nation has control over the currency in which debt is issued (De Grauwe, 2011a) ${ }^{6,7}$ As a result, the problem of default risk is higher for nations within a monetary union, unless the countries of the monetary union provide some form of collective guarantee - but such arrangements seem restricted by the Lisbon Treaty. ${ }^{8}$ The European Stability Mechanism (ESM) underestimates the fragility, seemingly assuming that having a small backstop would generate sufficient confidence that the risk of default would be put at bay. (See, also, footnote 27 , below.)

The problem cannot be solved by the more-prosperous nation taking on a blanket liability for paying back country $j$ 's loan because that will lead to reckless lending to $j$. Nor can it be solved through quantitative easing of the kind announced by the ECB in January 2015. That can ease other problems but not the one that is the focus of this article. ${ }^{9}$ However, it is possible to design joint, inter-government liability that can mitigate a large part of this problem. Moreover, it is possible to design this in ways such that the borrowing nation as well as the nation taking on some of the liability can both gain. ${ }^{10}$ Current arrangements for mutualisation of liability at the EU level require the concurrence of all countries, with different interests and perspectives, and are framed

\footnotetext{
${ }^{5}$ Nor is there consolation in the popular view (supported by some theory and evidence (Stiglitz, 2010) that defaults and haircuts are not costly in the long-run because lenders quickly forgive and forget. There is mounting evidence that the costs on the defaulting nation are often huge and prolonged (see, for instance, Cruces and Trebesch, 2011).

${ }^{6}$ The euro area increased the risk of default in other ways: the single market led to economic divergence, as capital and talented individuals left crisis countries. See Stiglitz (2014, 2015).

7 There is indeed an open question as to why this was not more widely recognised before the full-fledged financial crisis broke out in 2008. Till then the borrowing costs of all euro area nations were virtually identical, though soon thereafter these diverged widely, thereby reflecting the market's recognition that sovereign debts of different euro area nations carried different default risks. Whether or not this was a case of investors not realising the differential risk remains a disputed question (Shiller, 2012, p. 154-5).

${ }^{8}$ As Wolf (2014, p. 47), in his book discussing not just the crisis in Greece and Cyprus but also Ireland, Portugal and Spain, points out, 'The view that government debt should be risk-free has a certain validity for countries that borrow only in money they create: at least the risk of outright default is low in such cases, though not the risk of deflation'.

9 Indeed, it could even worsen the problem. The flood of liquidity 'in search of yield' too might lead to excessive borrowing in the short run, increasing the risk of precisely the kind of default upon which this article focuses.

${ }^{10}$ For a recent analysis of borrower solidarity in the context of the euro area crisis, see Tirole (2012) and Claessens et al. (2012). See also Bolton and Jeanne (2011).
} 
in ways that at least some parties believe that there is a transfer of risk without any apparent gain. Our approach provides for a Pareto improvement and entails only two countries but it appears that even this limited approach is proscribed by the Treaty of Lisbon.

Before getting into the details of policy and applying to the euro area, it is useful to begin by writing down formally the nature of the interaction between the lending bank and the small states that borrow to invest in some project.

Here is a typical, stylised, lending model. A country $j$ needs $\$ B$ to start a project. If successful, the project will yield a return of $\$ X(>B)$. The probability of the project being successful is $p$, which depends on the effort, $e$, that the borrower, namely, country $j$, puts in:

$$
p=p(e), p^{\prime}(e)>0, p^{\prime \prime}(e)<0 .
$$

If the project fails, the return is 0 .

The nation has no money of its own to make this initial investment of $B$. So it needs a lender or lenders to give it the money. Suppose, there are large numbers of lenders that have access to money at zero (for simplicity) interest rate and can lend this money to $j$. Because the market is competitive, the lender, henceforth, Bank, earns zero profit.

If the project fails, returns are zero and $j$ does not repay anything. This could be because a bankruptcy law exonerates the borrower from having to repay in such a situation. But there is widespread evidence that this kind of limited liability works even in the absence of any formal law (Basu, 1989). Similarly, in the international context, while no formal bankruptcy law governs sovereign debt, sovereign immunity provides de facto limited liability. ${ }^{11}$

We shall here assume that $j$ is simply not in a position to pay in the event of the project failing. The country may be too small and poor to be able to pay this back in the event of the project failing.

Limited liability introduces a standard moral hazard problem, resulting in the borrowing country putting in less effort than is 'efficient', in the sense of maximising the value of (global) output. ${ }^{12,13}$

\footnotetext{
11 Recent court decisions in the US in connection with Argentina's debt restructuring seemed to have put into question the principle of sovereign immunity. The ambiguities and uncertainties arising from the absence of a clear framework for sovereign debt restructuring may exacerbate the moral hazard problem and introduce additional distortions associated with the restructuring itself. This has led to a number of calls for an international framework for sovereign debt restructuring. See, for instance, the report of the UN Commission of Experts on Reforming the International Monetary and Financial Systems in the Wake of the Global Crisis and the UN resolutions based on that report (commonly referred to as the Stiglitz Report, available on the web and from New Press, 2010) and 'IMF's Greek apology shows a bankruptcy code is needed', by Komal Sri-Kumar Financial Times, 22 June 2013, p. 22). On 6 September 2014, the UN General Assembly voted to establish a process for establishing such a framework, and on 5 December 2014, the UN's Second Committee approved a draft proposal (128 to 4, with only the US, Japan, Israel and Canada voting against.)

12 Concerns about moral hazard have also repeatedly been raised in discussions of providing bail-outs. See the Economist magazine (15-21 June 2013, p. 14 and Brooke et al. (2013).

${ }^{13}$ There is a large literature on the (Pareto) efficiency of markets in which a moral hazard problem of the kind we have just described arises. In a single good world, it can be shown that the competitive equilibrium (described below) is in fact Pareto efficient but, in the context of an economy with multiple goods, it is not (Greenwald and Stiglitz, 1986). Further complexities (which we ignore in this article) arise when there are multiple loans (Arnott and Stiglitz, 1991).
} 
Suppose the lender offers the loan of $B$ and asks for a repayment of $D$. We assume that the contract does not and cannot specify the level of $e$. This could be because the effort put in by $j$ is not visible to the Bank. Alternatively, we can assume that it is visible to $j$ and the Bank but it is not possible to write it in a contract and have it verified and enforced by a court.

Assuming that the cost of each unit of effort is $c$, country $j$ faces the following problem. It has to choose $e$ so as to

$$
\operatorname{Max} p(e)(X-D)-c e .
$$

From the first-order condition, we know ${ }^{14}$

$$
p^{\prime}(e)(X-D)=c .
$$

Since the Bank is assumed to face a competitive market, its profit in equilibrium is zero. Hence

$$
p(e) D=B \text {. }
$$

The values of $e$ and $D$ which solve (2) and (3) describe the 'equilibrium' of the bilateral lending model. We shall assume that an equilibrium exists and denote the equilibrium by $\left(e^{\circ}, D^{\circ}\right)$.

Some properties of the equilibrium are worth noting. It is obvious that $D^{\circ} \geq B$. Otherwise, (3) would be violated. Now, define $e^{*}$, the value of effort which maximises expected returns, $p(e) X-c e$. In other words, $e^{*}$ is given by $p^{\prime}\left(e^{*}\right) X=c$. Because $D^{\circ}>0$ and $p^{\prime \prime}(e)<0$, it follows $e^{\circ}<e^{*}$.

$e^{*}$ also maximises the joint profits, $\Omega$, the sum of borrowers expected returns $p(e)(X-D)-c e$ and the Bank's earnings, $p(e) D-B$.

$$
\Omega(e) \equiv p(e)(X-D)-c e+p(e) D-B=p(e) X-c e-B .
$$

Clearly, $\Omega(e)$ is maximised when $p^{\prime}(e) X=c$, that is at $e^{*}$. Since $p^{\prime \prime}(e)<0$, this is unique. Hence,

$$
\Omega\left(e^{*}\right)=p\left(e^{*}\right) X-c e^{*}-B>p\left(e^{\circ}\right) X-c e^{\circ}-B=\Omega\left(e^{\circ}\right) .
$$

This establishes the sub-optimality of the bilateral equilibrium, $\left(e^{\circ}, D^{\circ}\right)$, viewed from the perspective of aggregate income. ${ }^{15}$ The bilateral equilibrium is dominated by $\left(e^{*}, D\right)$, for all $D$.

Define $\delta$ as the welfare (output) loss that occurs in the bilateral equilibrium relative to the first best:

$$
\delta \equiv\left[p\left(e^{*}\right) X-c e^{*}\right]-\left[p\left(e^{\circ}\right) X-c e^{\circ}\right] .
$$

It is useful to represent these ideas diagrammatically. In Figure 1, the horizontal axis represents the effort, $e$, put in by the borrowing country. The Figure also shows the curves $p(e) X$ and $c e$. Since aggregate welfare maximises $p(e) X-c e-B$ and $B$ is a

\footnotetext{
14 The expected return to the Bank is $p[e(D)] D$, and even under our strong assumptions, this may not be a monotonic function of $\mathrm{D}$, so that there can be more than one value of $D$ for which $p[e(D)] D=B$. If so, the market equilibrium is the lowest value (with $e$ being correspondingly the highest value).

${ }_{15}$ This is distinct from another form of inefficiency widely discussed in the international debt literature, namely, one associated with 'loan pushing' (Darity and Horn, 1986; Basu and Morita, 2006).
} 


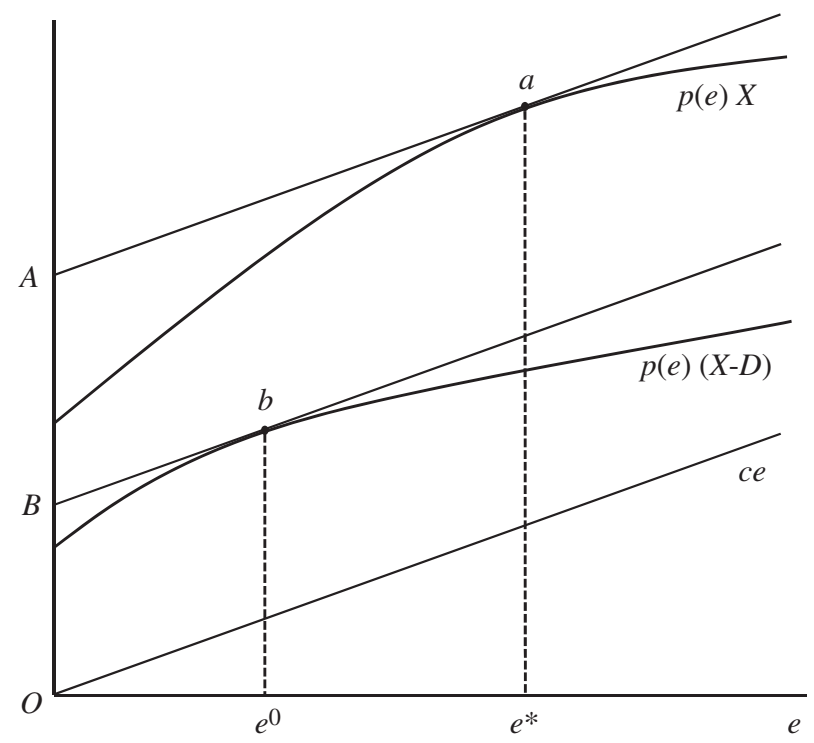

Fig. 1. The Sub-optimality of the Equilibrium

constant, it is easy to see that aggregate welfare is maximised at $e^{*}$, where the tangent to the curve $p(e) X$ is parallel to the line denoting $c e$.

Next, draw in the same Figure the curve $p(e)(X-D)$. Since the borrowing country maximises $p(e)(X-D)-c e$, its optimum occurs at $e^{\circ}$, where the tangent to the $p(e)(X-D)$ curve is parallel to the line denoting $c e$. Since the slope of the $p(e)(X-D)$ curve is obviously less than the $p(e) X$ curve at each pair of vertically aligned points, it is obvious that $e^{\circ}$ is to the left of $e^{*}$. In other words, in equilibrium, there is less effort than is optimal.

Is there a design that can recover this lost efficiency? The answer is yes, as we show in the next Section.

\section{Trilateral Contract Design}

For the lender and the borrower in the above Section to try to change this equilibrium on their own is hopeless. If the lender asks for some different level of $D^{*}$ (not equal to zero) back, it is still not optimal for the borrower to put in $e^{*}$ effort. In fact, if $D^{*}>D^{\circ}$, the borrowing nation will put even less effort than $e^{\circ}$.

This is where a third player that is well off and has close connections with $j$ can play a vital role. To see this consider another country $k$ with whom $j$ has a lot of interaction trade or capital flows or joint ventures - and mutual gain. ${ }^{16}$ It is possible that $j$ and $k$

16 The idea of how an uninvolved third party can alter the relation between two economic agents has had a long, if somewhat sporadic, history (see, for instance, Akerlof, 1976; Hatlebakk, 2002; Villanger, 2006). The critical role of the 'third party' in supporting bilateral sovereign debt is also modelled in Cole and Kehoe (1997). The question of joint liability in the context of sovereign debt is recently developed in Dellas and Niepelt (2013), building on the model of Eaton and Gersovitz (1981). The focus in their study is however not as much on the use of joint liability to overcome bilateral inefficiencies and default as to explain why official lending acquires prominence over private lending in many situations. See the discussion below for further examples. 
belong to the same currency union, as is the case with Germany and Greece, or they are party to a pact which facilitates trade and business among them. ${ }^{17}$

Let us here suppose in particular that $k$ (we will sometimes refer to $k$ as Germany) does some business (a hydroelectric project) with $j$ which gives $j$ a return of $R$, high enough that it can generate surpluses for both $j$ and $k$. And suppose Germany or $k$ also gets a decent surplus from its dealings with Greece or $j$. It is now easy to see that there is scope for an efficient shared liability arrangement. Nation $k$ stands guarantor for the loan taken by the borrowing country $j$. In other words, if Greece's project fails, it assures the Bank that it will step in and repay the loan to the Bank. It asks Greece to put in the optimal amount of effort into the project and then changes the terms of the joint venture with Greece so as to make the new arrangement as acceptable to Greece as the old one. This will leave Greece and the Bank as well off as before, and Germany better off.

To model this more precisely suppose $j$ and $k$ have a joint business venture, which takes the form of the 'joint venture' game. If either $j$ or $k$ refuses to participate in this game the game yields nothing and they each earn 0 . If both participate the game yields a return of $A$, which the two players can share in any way. If we leave it at this, this would be a standard Nash bargaining game. But to fit this into the non-cooperative game framework being used thus far, let us describe a simple normal form game. Assume that each player has to choose a strategy from the following set $\{\phi\} \cup[0, A]$, that is, each can choose $\phi$ or any number between and including 0 and $A$. If either player chooses $\phi$, he is saying that she will not participate and both players get a payoff of 0 from the joint venture game. If both players choose a number from $[0, A]$, then, if the numbers they choose add up to $A$, each gets the number he choses; and, if the numbers they choose do not add up to $A$, each gets zero.

It is easy to verify, that this normal form game has lots of Nash equilibria. In particular, $(\phi, \phi)$ is a Nash equilibrium. So is any strategy pair $(a, b)$, such that $a+b=A$. This is because if $j$ chooses a, it is a best response for $k$ to choose $b$ and vice versa. And no other strategy pair is a Nash equilibrium. ${ }^{18}$

Assume now that in this joint venture game, the outcome that currently occurs is $(R, A-R)$, where $R$ is an element of the open interval $(0, A)$. So from this game $j$ earns $R$ and $k$ earns $A-R$. It is now possible to show that if the values of $A$ and $R$ that occur in the Nash equilibrium are sufficiently large, then this game can be used strategically to yield efficiency in the bilateral lending game between $j$ and $k$. This entails the use of joint debt liability. In particular, this requires $k$ to offer to stand as guarantor to $j$ 's debt. Thus, $k$ allows $j$ to take the loan from the Bank and makes the agreement that if $j$ 's project succeeds then $j$ pays back to the Bank what is owed and if it fails then $k$ assures that it will step in and repay the loan to the Bank on behalf of $j$.

\footnotetext{
17 The question of whether they should be part of a common currency area or a comity of nations with a special pact is another matter with half a century of debate (see Mundell, 1961, Farhi and Werning, 2012). See also Paul Krugman's 'Boring Cruel Romantics,' in New York Times, 20 November 2011.

18 The reader may wish to verify that the strategy pair $(\phi, a)$, where a is an element of the half open interval $[0, A)$, is not a Nash equilibrium. It is interesting to note that, of all these Nash equilibria, only ones characterised by $(a, b)$, where $a$ and $b$ both belong to the open interval $(0, A)$ constitute a strict Nash equilibrium, that is a Nash equilibrium from which any unilateral deviation leaves the deviating player worse off.
} 
Country $k$ will of course have no interest in getting into a deal like this, which gives $k$ nothing but a positive probability of a loss (equal to $B$ ). It will, however, be worthwhile for $k$ to make this offer if it can put in some subsidiary clauses. What $k$ has to do is to use the joint business venture contract tactically to force $j$ to put in effort $e^{*}$ into the hydro power project for which it was borrowing the money. It does this by threatening to pull out of the joint venture, that is to play the strategy $\phi$ in the joint venture game, if $j$ does not put in effort $e^{*}$ in the hydroelectric power project. In other words, if $j$ does not put in effort $e^{*}$ in the power project, then they both expect the outcome of the joint venture game to be $(\phi, \phi)$. Of course, the outcome is not renegotiation proof (Bernheim and Ray, 1989; Farrell and Maskin, 1989) but it is, nevertheless, a subgame perfect equilibrium outcome. ${ }^{19}$

Since the Bank is a competitive agent, the repayment that $j$ has to offer to the Bank is now $B$. This is because, with $k$ as guarantor, the Bank is now certain about getting back its money. Hence, as long as it gets back what it originally lent, to wit, $B$, it breaks even (recall that the Bank's opportunity cost of lending is zero).

Putting in an effort of $e^{*}$ causes the net income between the Bank and the lending country to rise by $\delta$, as defined by (4), plus $\left[1-p\left(e^{*}\right)\right] B$. The latter is the expected payment made by the guarantor nation $k$.

If this was all there was to it, country $j$ would be better off by $\delta+\left[1-p\left(e^{*}\right)\right] B$. That would however not be an equilibrium since $k$ would be worse off by this deal, since $k$ offers to pay up in case the hydro power project fails, which has a probability of $\left[1-p\left(e^{*}\right)\right]$. Now suppose $k$, while ensuring that $j$ puts in an effort of $e^{*}$ and $k$ standing guarantee of repaying the loan to the Bank in the event of the project failing, offers $j$ for their joint business venture a return of not $R$ (as was the case earlier) but $R-\left\{\delta+\left[1-p\left(e^{*}\right)\right]\right\}$. We require this expression to be greater than or equal to zero, which is possible if $R$ is sufficiently large. And $R$ can be sufficiently large, if $A$ is sufficiently large. We are assuming that to be the case.

In other words, once the new deal is offered by $k$, the Nash equilibrium in the joint venture game generates pay-offs:

$$
\left(R-\left\{\delta+\left[1-p\left(e^{*}\right)\right]\right\}, A-\left(R-\left\{\delta+\left[1-p\left(e^{*}\right)\right]\right\}\right)\right) .
$$

This leaves $j$ s position unchanged since the additional amount it gets by working harder on the hydro project and by $k$ giving guarantee to repay the loan in the event of project failure is exactly matched by what it loses out in the joint venture with $k$. Since the total cake among the three of them is now bigger and the Bank and country $j$ 's net positions are unchanged, country $k$ must be better off. In fact, it will be better off by exactly $\delta$.

${ }^{19}$ Under somewhat more stringent conditions, it is possible to construct a renegotiation proof equilibrium. The clue lies in creating a punishment for deviant behaviour in which some players are hurt but others benefit; in brief, the agents must not have a collective interest in disregarding the punishment (Benoit and Krishna, 1993). With some complications added, this is possible to create. For instance, if $k$ could sign a contract with still another party, requiring it to pay that party a sufficiently large sum should it enter a renegotiation with $j$, then it will not be in the interest of $k$ to renegotiate. Such a contract would itself be renegotiation proof. But there is a valid question about how essential renegotiation-proofness is for an equilibrium to be realistic. Much of the argument turns around a more basic question of whether it is realistic to assume that a group of rational agents can be caught in a bad equilibrium when there exists a Pareto superior equilibrium. In the context of an extensive form interaction where there are preset expectations going into a subgame, renegotiations can be costly, especially so in the presence of asymmetric information among the parties involved. 
To make $j$ strictly prefer this arrangement, $k$ could give $j$ a small additional payment, $\varepsilon$. This would result in $k$ earning $\delta-\varepsilon$ and $j$ earning $\varepsilon$ more than what it was earning in the original bilateral equilibrium. From a formal game-theoretic point of view this is not necessary. Our aim here is simply to show that in the context of sovereign debt there is scope for third party guarantees to improve the overall situation - to bake a larger cake, without paying special attention to the (no doubt important) distributional matters. It is indeed possible to have additional features in the regulatory system which enables a part of the enhanced benefits to accrue to the smaller country that was doing the borrowing in the first place.

In brief, there exists a fully self-enforcing outcome in which $k$ makes country $j$ put in an effort of $e^{*}$ and accepts the liability to repay $j$ 's debt in the event of the hydro power project failing and re-specifies the terms of the joint business venture that $j$ and $k$ were engaged in. If $j$ reneges and undertakes a level of effort below $e^{*}$, then $j$ pulls out of the venture and so does $k$ : it is an equilibrium for both of them to do so; knowing that that is the case means that it is optimal for $j$ to provide the level of effort $e^{*} .^{20}$

It is possible to write this entire range of interactions, starting with the Bank and $j$, and then bringing in $k$ and the joint venture game, as one extensive-form game so that this joint liability contract and the strategies it specifies is part of a subgame perfect equilibrium. The argument critically hinges on the existence of multiple equilibria in the joint venture game which is a subgame of the full extensive-form game.

In analysing the result it is important to pay attention to the timing of the game. The Bank will not provide the money until $k$ offers the guarantee, which it will do only after $j$ makes a commitment to effort $e^{*}$. And it puts in the effort only after it has undertaken the project, that is, received the money.

If $k$ offers the guarantee before $j$ has exerted his level of effort, then there is always a problem that $j$ will renege on his commitment. $j$ will do this if he believes that $k$ will not pull out of the joint venture, because it is not in $k$ 's interest to do so. There is a precommitment problem. If $k$ pulls out of the project, it loses its investment and nets zero but is still liable for the guarantee. If $k$ does not pull out of the project, its return is $A-R+\delta+\left[1-p\left(e^{*}\right)\right]$. If $A-R+\left\{\delta+\left[1-p\left(e^{*}\right)\right]\right\}>0$, it will clearly not pull out of the project. In our case, we solve the 'commitment' problem by constructing the last period game, namely, the joint venture game, in such a way that it has multiple equilibria. It is this that allows us to establish subgame perfection. The equilibrium we establish is not renegotiation proof but it satisfies dynamic consistency (see, for instance, Gibbons, 1992). ${ }^{21}$

\subsection{Alternative Frameworks for Third Party Enforcement}

While the above argument makes critical use of multiple equilibria, it is possible to reach similar conclusion without them. What follows are some alternative approaches for the case where the joint venture game may not have multiple equilibria. If third party enforcement were possible, then $k$ could take $j$ to court for reneging on its

\footnotetext{
20 As we explain below, this is not the only way of enforcing 'good' behaviour. In fact, there are other ways of formulating multiple equilibria. In the next Section, we illustrate some alternatives.

21 But see footnote 19 above.
} 
contract. But that begs the question, if third party enforcement were possible (e.g. because $e$ is observable), why could $i$ have not taken $j$ to court? Of course, it may be possible that in courts to which $i$ and $j$ submit themselves, $e$ is not observable but $e$ is observable in courts to which $k$ and $j$ submit themselves.

There is a second possible way that the contract can be enforced. Assume there is a joint project whose return is positively correlated with the success of $i$ s project, such that, if $e<e^{*}$,

$$
\mathrm{EA}-R+\left\{\delta+\left[1-p\left(e^{*}\right)\right]\right\}<0,
$$

where EA denotes the expected return. Then $k$ can pull out of the project if and only if $j$ 'cheats'. The country may not be able to observe $e$ but there may be another signal that it could observe, which will tell the country to pull out of the project. And since $j$ knows this, it will be in his interest to exert $e^{*} .^{22}$

There is a third possible answer: contract enforcement arises not just because of the lack of observability of $e$ but because of sovereign immunity. Assume now that $e$ is discrete, the guarantor is a private party and the private party has made a contract (a Credit Default Swap, hereafter CDS) with another private party that if the default event occurs, that is $e<e^{*}$ and $k$ has not pulled out of the contract (abrogated the project), then he must pay an amount $Z$. Then $k$ 's calculus is different. If $k$ observes that $j$ has reneged, his expected return if he does not pull out of the contract is

$$
\mathrm{EA}-R+\left\{\delta+\left[1-p\left(e^{*}\right)\right]\right\}-Z<0, \text { for } e<e^{*},
$$

where $Z$ is the payment under the CDS. If he does pull out of the contract his return is zero. Hence, it pays him to pull out of the contract.

Finally, a fourth possibility. Assume $i$ and $j$ are in a one-time relationship (and/or $i$ cannot observe $e$ ), while $j$ and $k$ are in a repeated relationship (and $k$ can observe $e$ ). Then even if $e$ cannot be verified to a third party and/or there is not a court to which $i$ and $j$ are subject to contract enforcement, $j$ will behave well in its relationship to $k$, because of the value of its ongoing relationship.

\subsection{Earlier Literature}

Both joint liability (including co-signing provisions in contracts) and peer monitoring arguments are familiar in the literature. Peer monitoring associated with insurance contracts between $j$ and $k$ without joint liability has been shown to improve insurance markets when both $k$ and $i$ have issued insurance against the same risk: lender $i$ can infer that $k$ will ensure that $i$ behaves 'well' and thus will offer better terms such as a lower premium (Arnott and Stiglitz, 1991). ${ }^{23,24}$ The theory of peer monitoring

\footnotetext{
${ }^{22}$ For $j$ 's incentives to be altered, it must receive enough of a benefit from the project for it to choose $e^{*}$. If $k$ and $j$ had agreed to undertake that project before the new hydroelectric project came up, then $j$ 's moral hazard problem would already have been mitigated. What our model suggests is a deal, combining a guarantee and a joint project, in which the payments to $k$ make it worthwhile for both parties but without the bond deal, where there are no terms under which $k$ would sign that are acceptable to $j$.

${ }^{23}$ This is an example of an information externality, where monitoring by one party conveys information to another. Peer monitoring is but one example.

24 Similarly, Stiglitz and Yun (2013) show that co-signing of loans in the context of a period of unemployment can lead to Pareto superior outcomes because of peer monitoring; but they simply assume that the co-signer has the ability and incentive to enforce good behaviour, for example as a result of family ties.
} 
associated with joint liability among a group of borrowers has provided microfoundations for the success of microfinance but the incentive to co-sign the loan is simpler than here: individuals simply cannot get the loan without an agreement to co-sign and co-signing then provides the incentive to monitor (Stiglitz, $1990^{25}$ ). ${ }^{26}$

This article goes beyond these earlier studies by identifying a contractual relationship which leads to a subgame perfect equilibrium which is a Pareto improvement. In other words, the widespread assumption, that for the bigger country to provide a guarantee for another sovereign's debt is for taxpayers of the bigger nation to have to shoulder the burden of the borrowing sovereign's excesses, is not necessarily true (Sinn, 2014, ch. 8). It is possible to design liability contracts whereby all parties are better off. Of course, a potential Pareto improvement does not always translate into an actual Pareto improvement. But the serious political risk is not of the more powerful nation losing out but the smaller and poorer one coming out worse off in the end because of the lack of the guarantee.

\section{Policy Implications}

The central implication of the above formal analysis is the need to have scope for one sovereign to take on some of the liabilities of the debt of other sovereigns. At the very least, the concept of what is often pejoratively called a 'liability union' (Schwarzer and Lang, 2012) to accompany a monetary union and a single market is not to be dismissed out of hand.

The conditions under which mutually beneficial arrangements, whereby one country guarantees the debt of another, are, in fact, quite plausible. The sovereign providing the guarantee must have:

(i) the ability to impose costs on $j$ should it renege on its agreement to behave well, that is to provide the agreed upon level of effort;

(ii) the incentives to impose such costs; and

(iii) the ability to get compensated for having provided the guarantee, because even when $j$ does everything it is supposed to, there is some chance that $j$ will not be able to repay what is owed.

We argue that these conditions are plausibly satisfied and that there is a contract which could be voluntarily entered into by $j$ and $k$, and which leads to a subgame perfect equilibrium.

\footnotetext{
25 A lacuna in that paper, however, is that it is simply assumed that the members of the group can ensure that others behave appropriately, that is exert the right level of effort. There is no analysis of the consequences to the members of the group from reneging on their promise to behave well (other than the implicit cost of not being able to get access to future microfinance - the value of this access is sufficiently high that it is assumed that members of the group will not renege). More recent literature has formalised this 'value of access'. Still more recently, Haldar and Stiglitz $(2013 a, b)$ have argued that good behaviour is motivated not just by the value of access but by the social obligations ('social capital') that is built up as part of the lending programme. For a more recent discussion of joint liability in lending, see Ghatak and Guinnane (1999).

26 There is a related concept in which bank monitoring (not quite a peer) provides information to capital markets, where monitoring is weak. Capital markets free ride on banking monitoring in a way similar to the situation here. It is not that the bank guarantees the capital market loan, but cross default clauses/covenants can be designed to exploit the bank's superior information and incentives (Stiglitz, 1992).
} 
In the case of the euro area, for two countries to engage in what might seem to be mutually beneficial arrangements of this kind would run afoul of the Treaty of Lisbon. There are some limited ways in which the euro area can get around this legal constraint and some of them are being tried now. We have already referred to the ESM, which is a specially designed permanent crisis resolution mechanism that may purchase sovereign bonds from the primary market when these are issued by ESM members. Related to this is the Outright Monetary Transactions (OMT) programme announced by the ECB President, Mario Draghi, on 6 September, 2012. This will facilitate the purchase of euro area sovereign bonds by the ECB from the secondary market, and run in tandem with ESM macroeconomic adjustment programmes. But buying a government's bonds is equivalent to being a guarantor only if there is a commitment to buy all of them at par. There is neither the commitment nor the ability to do so. Moreover, these are facilities that are relevant after bonds have been issued and matters have not gone well. Our proposal concerns agreements at the time of the bond issue intended to enhance the probability that they will go well. It is, however, arguable that acting through a surrogate body such as the ESM will not be adequate for these purposes. ${ }^{27}$

The biggest stumbling block in applying these ideas to policy is Article 125 of the Treaty of Lisbon, which effectively rules out one nation from taking on the liability of another nation with its so-called 'no bail-out clause'. ${ }^{28}$ Actually, this hurdle was already there in advance of the Lisbon Treaty, which came into force only on December 1, 2009, in the Maastricht Treaty of 1992.

Relatedly, not only are individual countries proscribed from engaging in such liability sharing arrangements but also Article 123 of the Treaty of Lisbon prohibits direct credit from the ECB to any sovereign and also disallows the purchase of government bonds from the primary market. ${ }^{29}$ As a consequence of this the ECB is not a lender of last resort to any government but only to banks (Schafer, 2012). These constraints have clearly fed into euro area's sovereign debt problem (Pisani-Ferry et al., 2013). Both Article 123 and Article 125 need amendment. However, our central concern in the present study is with Article 125 of the Treaty of Lisbon. Monetisation of debt by a central bank (or dealing with the debt legacy problem of the euro area economies) and one nation taking on liabilities of another are two separate matters. What this article argues is for the Treaty to be amended to permit the latter.

It should be stressed that this article does not get into the politically contentious subject of sovereign rights and does not argue for the country providing the joint

\footnotetext{
27 As De Grauwe (2011b, p. 5) argues, referring to fact that the ESM has a limited budget, it 'will never have the necessary credibility to stop the forces of contagion; it cannot guarantee that the cash will always be available to pay out sovereign bond holders'.

Likewise the risks associated with sovereign defaults (and therefore the risk premia demanded by creditors) can be lowered making use of important ideas such as GDP-linked bonds (Griffith-Jones and Shama, 2006) and sovereign cocos but these are not enough for the problems of smaller and economically weaker nations that belong to the euro area and do not have their own central banks.

28 Bailouts are usually interpreted to mean ex post 'rescues', rather than ex ante risk-sharing arrangements, of the kind proposed here. It seems, however, that the general understanding is that Article 125 extends to such ex ante arrangements.

29 This provision is particularly strange, since it seemingly does not prevent a government from selling bonds to an intermediary (a bank) who might then sell it on (presumably at a commission). In short, one might view this provision more as a guarantee of income to financial intermediaries than a guarantee against sovereigns borrowing from central banks.
} 
liability to also have the right to coerce the borrowing nation to follow the former's preferred policy options. As such, the 'effort' in our model must not be construed as retrospective strictures on the indebted nation to alter policies. Our model demonstrates that, when nations have multiple forms of economic interaction, one such interaction (in our model, the joint ventures game between country $i$ and country $k$ ) can be leveraged to make a cross-country sovereign debt liability viable and the basis of mutual welfare enhancement. In our 'solution' coercion plays no role.

We do not address the actual mechanics and legislative process for amending it. The huge impediments to modifying even less central aspects of the EU architecture is itself a topic of major concern (De Witte, 2011). The problem was recognised early when in 1999, a 'group of wise men' chaired by the former Belgian Prime Minister Dehaene had discussed the importance of splitting up the European treaties into the more fundamental and less fundamental ones, in order to make it possible to respond to new contingencies and amend some parts of the architecture quickly. The current and ongoing euro area crisis shows that we still have some distance to go in creating scope for greater adaptability.

\section{Concluding Remarks}

It is useful to begin this Section by confronting a possible methodological criticism. If one shows (as we do in this article) that a group of agents can do better by behaving differently, the criticism is that there must be a flaw in the analysis because if people could have done better behaving differently, then they would already be doing so. This criticism must be false, because otherwise it would be hard pressed to explain why all the useful technologies we have now, we did not have earlier. The fact is social and behavioural innovations are in some ways similar to technological innovations. A behavioural innovation is nothing but the discovery of high returns associated with new combinations of behaviour. ${ }^{30}$ In this respect, it is similar to technological innovations, which rely on, for instance, discovering which chemical to mix with which. The aim of this study was to outline new strategies that can make international lending across nations that are inter-connected, such as the current European Union nations, more efficient.

This study was at one level the description of a simple, abstract 3-agent game but it was also - and that is what makes it significant - an allegory of many important, real-life problems. Could it pay for Germany and UK to take on the liability for debts incurred by Cyprus and Slovenia from some international investment banks? This article showed that the answer is yes and it also illustrated the design of a contract that can achieve this. Such a contract can improve credit flows to Cyprus and Slovenia. Lenders who may have no knowledge of and familiarity with these nations will be willing to lend, knowing that Germany and UK will use their standing, trading and other business relations with Cyprus and Slovenia as leverage to make these borrowing nations be

\footnotetext{
30 As Rubinstein (2012, p. 238) argues, 'Most of the players in the economic game have only limited familiarity with the economic game and make plenty of mistakes. ... Most economic players find it difficult to identify economic opportunities and respond to them. This is a problem for supporters of traditional economic thought ...
} 
more vigilant in the use of the credit and also stand as guarantor of last resort if the project for which money is borrowed fails. The extreme case of this model is that with the loan guarantee and 'supervision' there is no risk of default - so that the country giving the guarantee actually bears no risk.

The risk of default obviously increases with the interest rate charged and thus the guarantee by itself lowers the risk of default. ${ }^{31}$ It is easy to show that in 'moral hazard' models of the kind described here, where effort $e$ is a function of the interest rate charged and the interest rate charged is a function of the probability of default, and the probability of default is a function of effort and the interest rate charged, there can be multiple equilibria, that is multiple solutions to (2) and (3), a low interest rate, low default probability equilibrium and a high interest rate, high default probability equilibrium (Greenwald and Stiglitz, 2003). One of the functions of a guarantee from government $k$ is to ensure that the good equilibrium (low $r$, low $q$ ) prevails.

An easy modification of this model is one where no lending occurs when the interaction is entirely bilateral between the lender and $j$. This happens when (2) and (3) have no solution. This is easy to understand using the diagrammatic depiction of the bilateral equilibrium in Figure 1. This is compatible with there existing an $e$ for which $\Omega(e)>0$, where $\Omega(e)$ is defined as in Section 1. From Figure 1 it is obvious that the condition under which this happens (i.e. without a third party joint liability the credit market breaks down altogether and with third party joint liability there is an equilibrium with credit flowing to country $j$ ) is given by:

$$
p^{\prime}(0)(X-D) \leq c<p^{\prime}(0) X .
$$

In such cases, multilateral liability of the kind described in this study can not only be used to improve the credit market but to bring to life a credit market that would otherwise be moribund.

We have focused on one implication of this theoretical analysis: the need to amend the Treaty of Lisbon to allow the kind of efficiency enhancing contract that we have described. But there are many others. It is possible for lending organisations such as the World Bank, the IMF and even new entities such as the BRICS Bank or the World Bank Group's new Global Infrastructure Facility to adopt the ideas proposed in this study. This would make it possible to lend more, lend more widely, and to enhance efficiency.

\section{The World Bank and Cornell University Columbia University}

\section{References}

Akerlof, G. (1976). 'The economics of caste, and of the rat race and other tales of woe', Quarterly Journal of Economics, vol. 90(4), pp. 599-617.

Arnott, R. and Stiglitz, J. (1991). 'Moral hazard and nonmarket institutions: dysfunctional crowding out or peer monitoring', American Economic Review, vol. 81(1), pp. 179-90.

Basu, K. (1989). 'Technological stagnation, tenurial laws and adverse selection', American Economic Review, vol. $79(1)$, pp. 251-5.

31 This can be seen directly in the model of Section 2 but holds more generally (Stiglitz and Weiss, 1981). 
Basu, K. (1991). 'International debt problem, credit rationing and loan pushing', Princeton Studies in International Finance, No. 70.

Basu, K. and Morita, H. (2006). 'International credit and welfare: a paradoxical theorem and its policy implications', European Economic Review, vol. 50(6), pp. 1507-28.

Benoit, J.-P. and Krishna, V. (1993). 'Renegotiation in finitely-repeated games', Econometrica, vol. 61(2), pp. 303-23.

Bernheim, B. D. and Ray, D. (1989). 'Collective dynamic consistency in repeated games', Games and Economic Behavior, vol. 1(4), pp. 295-326.

Bolton, P. and Jeanne, O. (2011). 'Sovereign default risk and bank fragility in financially integrated economies', IMF Economic Review, vol. 59(2), pp. 162-94.

Brooke, M., Mendez, R., Pienkowski, A. and Santor, E. (2013). 'Sovereign default and state-contingent debt', VOX CEPR Policy Portal, 12 December. Available at: http://www.voxeu.org/article/sovereign-default-andstate-contingent-debt (last accessed: 5 May 2015).

Claessens, S., Mody, A. and Vallee, S. (2012). 'Paths to Eurobonds', Working Paper No. 12/172, IMF.

Cole, H. and Kehoe, P. (1997). 'Reviving reputation models of international debt', Quarterly Review, Federal Reserve Bank of Minneapolis, Winter, vol. 21(1), pp. 21-30.

Cruces, J. and Trebesch, C. (2011). 'Sovereign defaults: the price of haircuts', Working Paper No. 3604, CESifo.

Darity, W. and Horn, B. (1986). The Loan Pushers: The Role of Commercial Banks in the International Debt Crisis, Cambridge, MA: Ballinger.

De Grauwe, P. (2011a). 'The governance of a fragile Eurozone', Working Document No. 346, CEPS.

De Grauwe, P. (2011b). 'The European central bank as lender of last resort', VOX CEPR Policy Portal, 18 August. Available at: http://www.voxeu.org/article/european-central-bank-lender-last-resort (last accessed: 5 May 2015).

De Witte, B. (2011). 'The European treaty amendment for the creation of the financial stability mechanism', SIEPS European Policy Analysis, June, issue vol. 6.

Dellas, H. and Niepelt, D. (2013). 'Credibility for Sale', Working Paper No. 4335, CESifo.

Eaton, J. and Gersovitz, M. (1981). 'Debt with potential repudiation: theoretical and empirical analysis', Review of Economic Studies, vol. 48(2), pp. 289-309.

Farhi, E. and Werning, I. (2012). 'Fiscal unions', Working Paper No. 18280, NBER.

Farrell, J. and Maskin, E. (1989). 'Renegotiation in repeated games', Games and Economic Behavior, vol. 1, pp. 327-60.

Ghatak, M. and Guinnane, T. (1999). 'The economics of lending with joint liability: theory and practice', Journal of Development Economics, vol. 60(1), pp. 195-228.

Gibbons, R. (1992). Game Theory for Applied Economists, Princeton, NJ: Princeton University Press.

Greenwald, B. and Stiglitz, J. (1986). 'Externalities in economies with imperfect information and incomplete markets', Quarterly Journal of Economics, vol. 101(2), pp. 229-64.

Greenwald, B. and Stiglitz, J. E. (2003). Towards a New Paradigm in Monetary Economics, Cambridge: Cambridge University Press.

Griffith-Jones, S. and Sharma, K. (2006). GDP-indexed bonds: Making it happen. DESA Working Paper 21. United Nations.

Haldar, A. and Stiglitz, J. (2013a). 'Analyzing legal formality and informality: lessons from land-titling and microfinance programs', in (D. Kennedy and J. Stiglitz, eds.), Law and Economic Development with Chinese Characteristics, pp. 112-48, Oxford: Oxford University Press.

Haldar, A. and Stiglitz, J. (2013b). 'The Indian microfinance crisis: the role of social capital, the shift to forprofit lending and implications for microfinance theory and practice', mimeo, Columbia University. Available at: http://cgt.columbia.edu/wp-content/uploads/2014/01/The-Indian-Microfinance-Crisis. pdf (last accessed: 5 May 2015).

Hatlebakk, M. (2002). 'A new and robust subgame perfect equilibrium in a model of triadic power', Journal of Development Economics, vol. 68(1), pp. 225-32.

Mundell, R. (1961). 'A theory of optimum currency areas', American Economic Review, vol. 51, pp. 657-65.

Pisani-Ferry, J., Sapir, A. and Wolff, G. (2013). 'EU-IMF assistance to the euro area countries: an early evaluation', Bruegel Blueprint Series, 19, Brussels.

Rubinstein, A. (2012). Economic Fables, Cambridge: Open Book Publishers.

Schafer, H. (2012). 'The sovereign debt crisis in Europe, save banks not states', European Journal of Comparative Economics, vol. 9(2), pp. 179-95.

Schwarzer, D. and Lang, K. O. (2012). 'The myth of German hegemony', Foreign Affairs, 2 October, Available at: http://www.foreignaffairs.com/articles/138162/daniela-schwarzer-and-kai-olaf-lang/the-myth-of-ger man-hegemony (last accessed: July 25, 2013).

Shiller, R. J. (2012). Finance and the Good Society, Princeton, NJ: Princeton University Press.

Sinn, H. W. (2014). The Euro Trap: On Bursting Bubbles, Budgets, and Beliefs, Oxford: Oxford University Press. Stiglitz, J. (1990). 'Peer monitoring and credit markets', World Bank Economic Review, vol. 4(3), pp. 351-66. 
Stiglitz, J. (1992). 'Banks versus markets as mechanisms for allocating and coordinating investment', in (J.A. Roumasset and S. Barr, eds.), The Economics of Cooperation: East Asian Development and the Case for ProMarket Intervention, pp. 15-38, Boulder, CO: Westview Press.

Stiglitz, J. (2002). Globalization and Its Discontents, New York: Norton \& Co.

Stiglitz, J. (2010). 'Sovereign debt: notes on theoretical frameworks and policy analyses', in (B. Herman, J.A. Ocampo and S. Spiegel, eds.), Overcoming Developing Country Debt Crises, pp. 35-69, Oxford: Oxford University Press.

Stiglitz, J. (2014). 'Can the Euro Be Saved? An Analysis of the Future of the Currency Union', Rivista di Politica Economica, vol. 3, pp. 7-42.

Stiglitz, J. (2015). 'Monetary policy in a multipolar world', in (J. Stiglitz and R. Gurkaynak, eds.), Taming Capital Flows: Capital Account Management in an Era of Globalization, pp. 124-70, London: PalgraveMcMillan.

Stiglitz, J. and Weiss, A. (1981). 'Credit rationing in markets with imperfect information', American Economic Review, vol. 71(3), pp. 393-410.

Stiglitz, J. and Yun, J. (2013). 'Optimal provision of loans and insurance against unemployment from a lifetime perspective', Working Paper No. 19064, NBER.

Tirole, J. (2012). 'Country solidarity, private sector involvement and the contagion of sovereign crises', mimeo, Toulouse School of Economics.

Villanger, E. (2006). 'Company interest and foreign aid policy: playing donors out against each other', European Economic Review, vol. 50(3), pp. 535-45.

Wolf, M. (2014). The Shifts and the Shocks: What We've Learned - and Have Still to Learn - From the Financial Crisis, New York: Penguin.

Zettelmeyer, J., Trebesch, C. and Gulati, M. (2013). 'The Greek debt restructuring: an autopsy', Working Paper 13-8, Petersen Institute for International Studies. 
Copyright of Economic Journal is the property of Wiley-Blackwell and its content may not be copied or emailed to multiple sites or posted to a listserv without the copyright holder's express written permission. However, users may print, download, or email articles for individual use. 